Provided for non-commercial research and education use. Not for reproduction, distribution or commercial use.

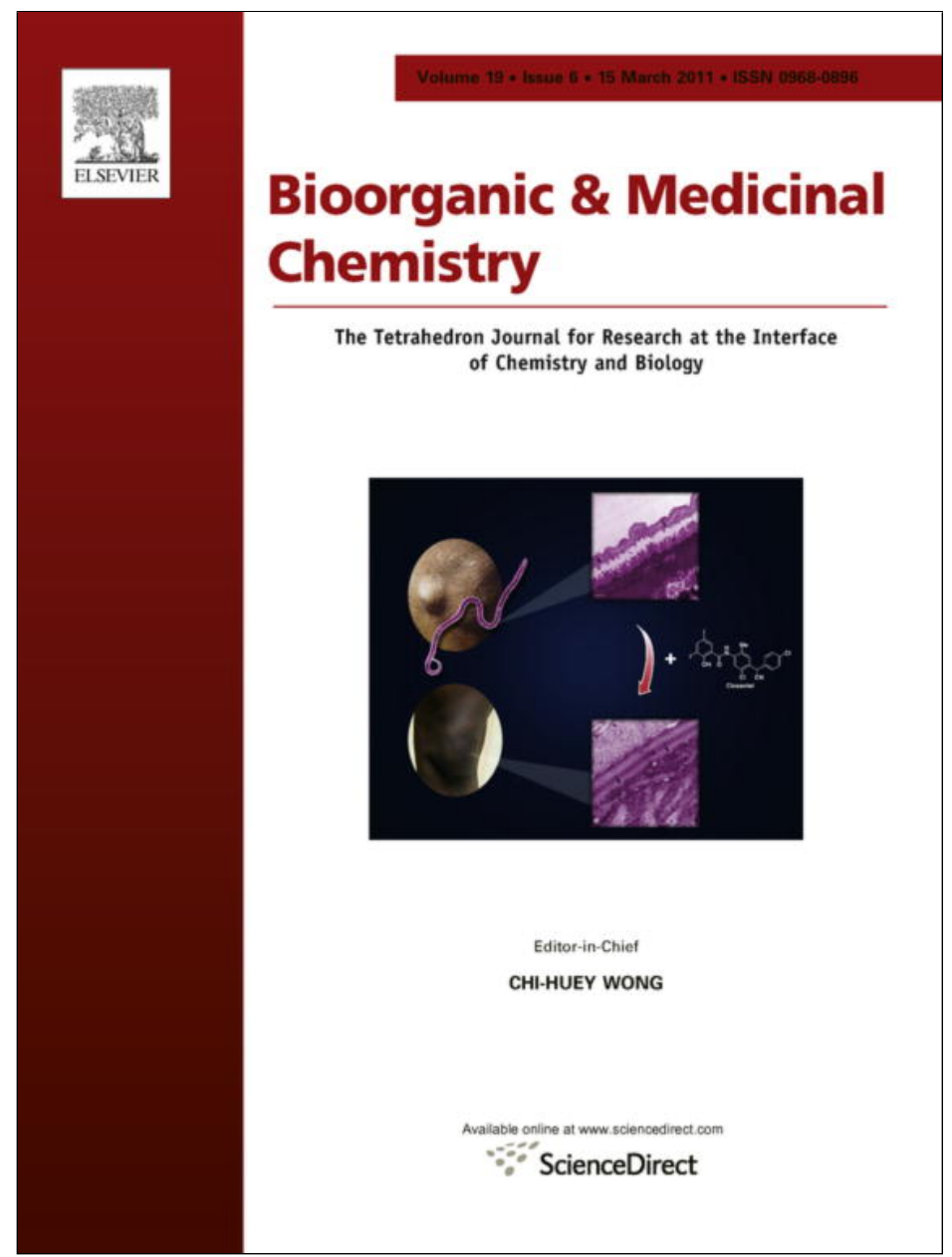

This article appeared in a journal published by Elsevier. The attached copy is furnished to the author for internal non-commercial research and education use, including for instruction at the authors institution and sharing with colleagues.

Other uses, including reproduction and distribution, or selling or licensing copies, or posting to personal, institutional or third party websites are prohibited.

In most cases authors are permitted to post their version of the article (e.g. in Word or Tex form) to their personal website or institutional repository. Authors requiring further information regarding Elsevier's archiving and manuscript policies are encouraged to visit:

http://www.elsevier.com/copyright 


\title{
MMT, Npeoc-protected spermine, a valuable synthon for the solid phase synthesis of oligonucleotide oligospermine conjugates via guanidine linkers
}

\author{
Phanélie Perche, Mitsuharu Kotera*, Jean-Serge Remy \\ Laboratoire de Chimie Génétique, UMR7199 CAMB, CNRS et Université de Strasbourg, Faculté de Pharmacie, 67401 Illkirch, France
}

\section{A R T I C L E I N F O}

\section{Article history:}

Received 15 October 2010

Revised 26 January 2011

Accepted 28 January 2011

Available online 2 February 2011

\section{Keywords:}

Guanidine

Oligonucleotide conjugates

Spermine oligomer

Solid phase synthesis

\begin{abstract}
A B S T R A C T
Solid phase spermine oligomerization via guanidine linkers was achieved using activated thiourea coupling reaction with primary amino group. Disymmetric spermine synthon was efficiently synthesised in eight steps from spermine. MMT group was used as coupling monitor and resulting oligomeric spermines were conjugated to oligonucleotides.
\end{abstract}

(c) 2011 Elsevier Ltd. All rights reserved.

\section{Introduction}

Synthetic vectors based on electrostatic interactions with nucleic acids and cell membranes such as cationic lipids, cationic polymers or cationic peptides particles have been extensively used to carry genetic material into cells. Though efficient in vitro, they suffer from in vivo limitations for example, aggregation, poor tissue distribution. With the emergence of oligonucleotides as new tools to control gene expression (antisense oligonucleotides, siRNA), vectorization can now be performed by oligonucleotides covalent conjugation to residues responsible for their internalization (CPP oligonucleotide conjugates, lipidic oligonucleotides). Cellular uptake at the single molecule scale instead of particle level should enhance in vivo distribution.

In our effort to switch from particles to molecules for cell delivery, we have developed new cationic oligonucleotide-polyamines conjugates (ZNA i.e., structure 13 in Scheme 2). ${ }^{1,2}$ These compounds were obtained by repetitive coupling of a natural polyamine, the spermine through the well-known phosphoramidite chemistry. These conjugates exhibited cell penetration potency and submicromolar activity. ${ }^{3}$ Fine-tuning the number of coupled spermines could also provide highly sensitive primers for PCR. ${ }^{4,5}$ In this article, we present our newly developed solid phase synthesis of oligonucleotide-oligospermine conjugates based on guanidinium link formation between spermine units. Such chemistry allows a faster increase of (cationic groups)/(phosphates) ratio (N/P ratio) compared to ZNA chemistry containing phosphate links

\footnotetext{
* Corresponding author. Tel.: +33 (0)3 6885 4175; fax: +33 (0)3 68854306 .

E-mail address: kotera@bioorga.u-strasbg.fr (M. Kotera).
}

between spermine units. Guanidine groups are also known to form high affinity interaction with phosphate groups, thus the resulting conjugates may have increased duplex stability. Several efficient solid phase syntheses of guanidinium oligomer have been described. ${ }^{6-11}$ We thus prepared a new spermine synthon (i.e., 10 in Scheme 1) bearing a MMT group on one $\mathrm{NH}_{2}$ end and a carbamoyl protected thiourea group at the distal end. Oligonucleotide-oligospermine conjugates with up to three spermine units were synthesised by solid phase chemistry. These conjugates were shown to gain increased duplex stability depending on the number of spermine introduced.

\section{Results and discussion}

\subsection{Spermine synthon synthesis}

The spermine synthon $\mathbf{1 0}$ was prepared on a $50 \mathrm{mmol}$ scale (Scheme 1). Orthogonal protection of primary and secondary amines was first achieved (to afford intermediate 3 ). Spermine was fully trifluoroacetylated to $\mathbf{1}$ and then treated with Boc anhydride to yield compound $\mathbf{2}$. The two terminal TFA groups were spontaneously deprotected by methanol treatment during workup to yield 3 (84\% three steps-overall yield from spermine). At this stage, it was shown that TFA groups were not suitable for secondary amino group protection. Indeed, Boc deprotection of $\mathbf{3}$ gave rapid TFA group transposition to afford compound $4 .^{12}$ Thus, the TFA groups were replaced by carbamate groups that are not transposable. (Nitrophenyl)ethoxycarbonyl (Npeoc) protecting groups had been reported to be compatible with oligonucleotide synthesis. ${ }^{13}$ It was found that the Npeoc group can be readily introduced on 

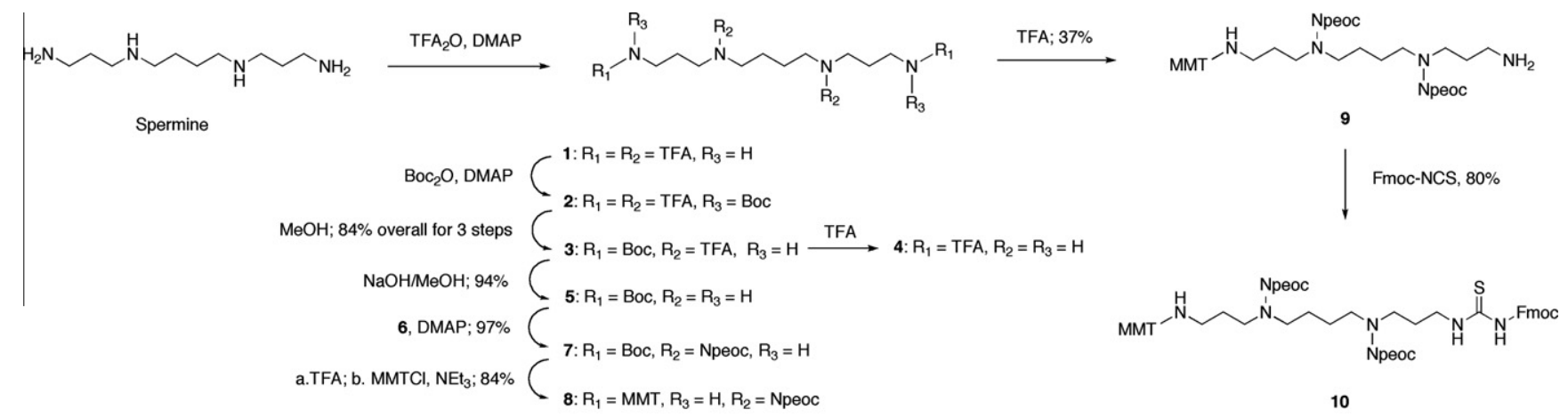

10

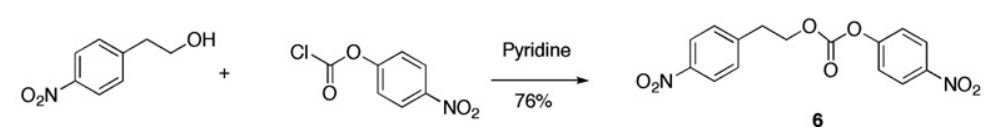

Scheme 1. Spermine synthon synthesis.
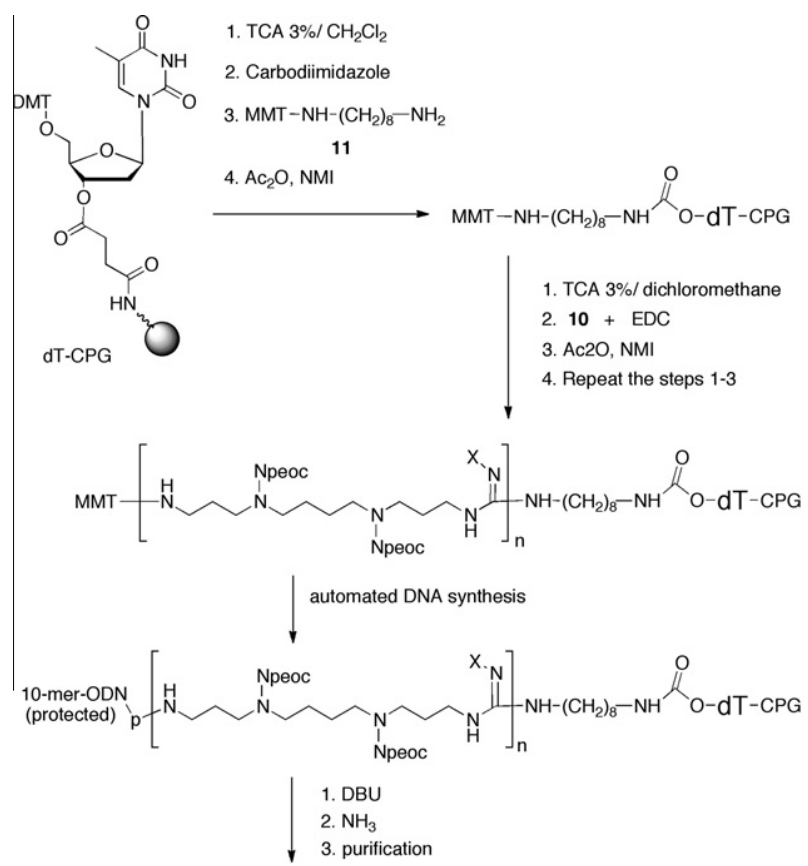

10-mer-ODN

12a $n=1 M_{\text {found }}=3715.1 M_{\text {calcd }}=3714.8$
12b $n=2 M_{\text {found }}=3941.6 M_{\text {calcd }}=3942.1$
12c $n=3 M_{\text {found }}=4169.5 M_{\text {calcd }}=4168.8$

10-mer-ODN = d (GCGATGCCAC)

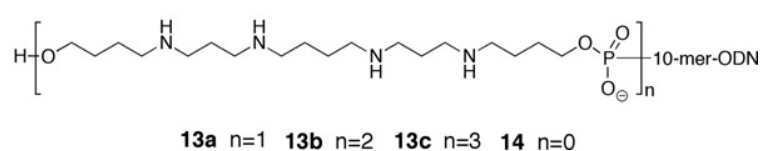

Scheme 2. Oligonucleotide-oligospermine conjugates synthesis.

secondary amine by the use of 4-nitrophenethyl 4-nitrophenylcarbonate $(\mathbf{6})$. Thus, we prepared the carbonate $\mathbf{6}$ by reaction of 4-nitrophenyl chloroformate with 4-nitrophenethyl alcohol under pyridine activation. TFA removal of compound 3 by $\mathrm{NaOH}$ in a methanol/water mixture afforded $\mathbf{5}$ and introduction of Npeoc group was then achieved by the carbonate $\mathbf{6}$ with DMAP to provide 7. These steps were optimised to give excellent yields (>91\% pro step) without using tedious column chromatography and the product 7 was shown to be of good purity, as revealed by elementary analysis. Boc groups of the primary amines of $\mathbf{7}$ were subsequently deprotected by TFA treatment (12 equiv) and crude TFA salts were treated by 4 -monomethoxytrityl chloride ( $\mathrm{MMTCl} ; 4.2$ equiv), with excess of triethylamine (20 equiv) to afford bis-MMT product 8 in good yield (79\%). Partial deprotection of MMT gave the desired mono MMT amine $\mathbf{9}$ and unreacted bis-MMT product $\mathbf{8}$ was recovered and recycled to afford overall yield up to $62 \%$ after three cycles. ${ }^{14}$ Finally the reactive thiourea was inserted by addition of $\mathbf{9}$ to a solution of Fmoc isothiocyanate in dichloromethane at $0{ }^{\circ} \mathrm{C}$ to afford $10(80 \%)$ after flash column chromatography purification, as a white, easy-to-handle foam.

\subsection{Oligonucleotide-oligospermine conjugates synthesis}

Spermines were oligomerized on solid support prior to oligonucleotide synthesis (Scheme 2) ${ }^{15} \mathrm{dT}$-CPG was first conjugated to a diaminolinker (C8) by successive treatment of TCA, carbodiimide and then mono MMT-protected diaminooctane 11. According to trityl assay, the conjugation efficiency was $75-80 \%$. In order to stop further participation of un-reacted sites, the solid support was finally treated in prolonged capping conditions $\left(\mathrm{Ac}_{2} \mathrm{O}, \mathrm{NMI}, 6 \mathrm{~min}\right)$. Several reagent-base combinations were examined for couplings of spermine synthon $\mathbf{1 0}$ including DCC, EDC, EDC methiodide and Mukaiyama reagent with the following bases: DIPEA, pyridine or NMI. The best results were obtained using 20 equiv synthon 11 with $\mathrm{EDC} \cdot \mathrm{HCl}$ activation ( 88 equiv) in presence of DIPEA (88 equiv) for $4 \mathrm{~h}$. The coupling yields determined by trityl assay attained $88 \% .{ }^{16}$ Unreacted sites were equally capped using $\mathrm{Ac}_{2} \mathrm{O} / \mathrm{NMI}$ reagent. The same protocol was used for the second and third coupling, affording similar coupling yields. The last MMT group was then detritylated and on-machine ODN synthesis was performed in standard conditions, except for the first coupling that used prolonged coupling time and repeated amidite delivery. ${ }^{17}$ The oligonucleotide-spermine conjugates were cleaved from CPG and base deprotection was carried out by concd $\mathrm{NH}_{4} \mathrm{OH}$ at room temperature for $24 \mathrm{~h}$. Ammonia solutions were lyophilized and the residual crude materials were suspended in DBU $1 \mathrm{M}$ /acetonitrile $\left(55^{\circ} \mathrm{C}\right.$ 3 days at rt) for Npeoc deprotection. ${ }^{18}$ After desalting, crude prod- 
Table 1

Melting temperatures $\left(T_{m},{ }^{\circ} \mathrm{C}\right)$ of duplexes containing conjugates $12 \mathbf{a}-12 \mathbf{c}^{\mathrm{a}}$

\begin{tabular}{rlc}
\hline ODN & $T_{m}\left({ }^{\circ} \mathrm{C}\right)$ & $\Delta T_{m}{ }^{\mathrm{b}}\left({ }^{\circ} \mathrm{C}\right)$ \\
\hline 12a & 49.3 & +2.9 \\
12b & 48.3 & +1.9 \\
12c & 50.4 & +4.0 \\
13a & 48.1 & +1.7 \\
13b & 49.3 & +2.9 \\
13c & 53.3 & +6.9 \\
14 & 46.4 & Ref.
\end{tabular}

a Melting temperatures were determined using a $1.0 \mu \mathrm{M}$ duplex concentration in $1 \mathrm{~mL}$ buffer composed of $10 \mathrm{mM}$ HEPES $\mathrm{pH} 7.4,0.15 \mathrm{M} \mathrm{NaCl}$.

b $T_{m}$ increase compared to the natural duplex (14).

ucts 12a and 12b were shown to be of good purity without further purification. For 12c, the final DMT group was kept during ODN synthesis and $\mathrm{C}_{18}$-based purification was carried after the same deprotection procedure to afford the final product. The conjugates $12 \mathrm{a}-\mathrm{c}$ were characterized by MALDI-TOF mass spectrometry.

Melting temperatures of duplexes containing the oligonucleotide conjugates 12a-c were determined and compared with those containing ZNA 13a-c prepared in our laboratory (Table 1$)^{2,3}$ The natural duplex melted at $T_{m}=46.4^{\circ} \mathrm{C}$. As expected, $\Delta T_{m}$ of guanidine linked spermine conjugates 12a is higher than corresponding ZNA $\left(+2.9^{\circ} \mathrm{C}\right.$ vs $\left.+1.7^{\circ} \mathrm{C}\right)$. Conjugates containing two and three spermines units (12b and 12c) show equally increased duplex stability compared to the natural duplex however stabilizing effect $\Delta T_{m} /$ (number of spermine units) for $\mathbf{1 2 b}$ and $\mathbf{1 2 c}$ were lower in these cases than that of ZNA. Surprisingly the second conjugation of spermine unit is shown to be destabilizing for duplex ( $T_{m}=48.3^{\circ} \mathrm{C}$ for $12 \mathbf{b}$ vs $T_{m}=49.3^{\circ} \mathrm{C}$ for 12a). The reason of this observation is still not understood. Addition of 3 spermines (12c and $13 \mathrm{c}$ ) resulted in $\Delta T_{m}$ in favor of phosphate linkages (+4.0 vs $+6.9^{\circ} \mathrm{C}$, respectively). We speculate that guanidine linkage being more rigid than phosphate, the resulting oligocation might not bend over the duplex to stabilize it.

\section{Conclusion}

We developed efficient synthesis of spermine synthon 10. We successfully oligomerized this synthon $\mathbf{1 0}$ on CPG support and the resulting oligospermine was successfully conjugated to oligonucleotide. Increased duplex stability was observed for these conjugates. Current study addresses the improvement of coupling efficiency of guanidine linkage and deprotection procedures in order to allow increased number of spermine couplings.

\section{Experimental section}

\subsection{General}

\subsubsection{Reagents and solvents}

Unless otherwise stated, all reagents were purchased from Sigma Aldrich, TCI and Merck and used without further purification. All solvents were purchased from Carlo Erba reagents-SDS or VWR-Prolabo. All synthesized compounds were characterized using standard analytical and spectroscopic techniques. Oligonucleotides were prepared on an automated Expedite 8900 Nucleic Acid Synthesis System (GMI Inc, USA) at $1 \mu \mathrm{mol}$ scale. $3^{\prime}$-dT-CPG $1 \mu \mathrm{mol}$ columns, (5'-dimethoxytrityl-3'-thymidine, 2'-succinoyllong chain alkylamino-CPG) were purchased from Glen Research. Oligonucleotide synthesis reagents, solvents and purification cartridges were all purchased from Glen Research/Eurogentec (Paris, France) except for external acetonitrile (Wash A), which was provided by Carlo Erba reagents-SDS. All phosphoramidites used were standard DNA phosphoramidites, with standard capping reagents (cap Mix A: $\mathrm{Ac}_{2} \mathrm{O} / \mathrm{THF} 1: 9$, Cap mix B: $10 \% N$-methylimidazole/ THF/pyridine: 1:8:1), 5-benzylthio[1H]tetrazole in acetonitrile as activator and $0.02 \mathrm{M} \mathrm{I}_{2}$ in $\mathrm{THF} /$ pyridine $/ \mathrm{H}_{2} \mathrm{O}$ as oxidizing solution.

\subsubsection{Analyses and purifications}

Melting points were measured in a Stuart Scientific SMP2 melting point apparatus 2 and are uncorrected. IR spectra were performed on a Nicolet 380 FT-IR with a Smart Orbit ATR Sampling Accessory from ThermoFischer. ${ }^{1} \mathrm{H}$ and ${ }^{13} \mathrm{C}$ spectra were performed either on a $400 \mathrm{MHz}$ Bruker Avance III instrument (BBFO+ probe), a $200 \mathrm{MHz}$ Bruker DPX spectrometer, or a $300 \mathrm{MHz}$ Bruker Avance DPX spectrometer with dual $\left({ }^{1} \mathrm{H},{ }^{13} \mathrm{C}\right)$ probe. NMR chemical shifts are reported as ppm relative to tetramethylsilane and converted to the TMS scale using the residual proton of the corresponding deuterated solvent. Data for ${ }^{1} \mathrm{H}$ NMR spectra are reported as follows: multiplicity $(\mathrm{s}=$ singlet, $\mathrm{d}=$ doublet, $\mathrm{t}=$ triplet, $\mathrm{q}=$ quartet, quintuplet, $\mathrm{m}=$ multiplet, $\mathrm{dt}=$ double triplet, $\mathrm{br}=$ broad), coupling constants, integration. Data for ${ }^{13} \mathrm{C}$ NMR spectra are reported as follows: DEPT attribution, integration. Due to the $\mathrm{C}-\mathrm{N}$ bond rotation retardation in trifluoroacetyl or carbamate functions, many ${ }^{13} \mathrm{C}$ signals were split in several peaks. Elementary analyses were performed by the CNRS Service Central d'Analyses, USR-59 on homemade microanalyzers. Mass spectrometry was carried out with positive ionization either on a LC-MS spectrometer Agilent1200 (LC) MM-ESI-APCI-MSD (MS), a MS Bruker (Ion Trap, HCT Ultra, ESI) or a MS Agilent (QTof 6520, ESI) spectrometer. Oligonucleotide mass spectra (MALDI-TOF) were obtained in the positive mode on a Bruker Ultraflex apparatus with hydroxypicolinic acid combined with diammonium citrate as matrix. UV/vis. absorption spectra were recorded on a Varian Cary 100 bio spectrophotometer. Merck Silica Gel $60 \mathrm{~F}_{254}$ plates were used for analytical thin layer chromatography. TLC analysis was facilitated by the use of the following stains in addition to UV light $(254 \mathrm{~nm})$ with fluorescent-indicating silica gel plates: $5 \%$ phosphomolybdic acid/EtOH or 5\% ninhydrin/EtOH. Merck Silica Gel 60 (particle: 40-63 $\mu \mathrm{m}$ ) was employed for column chromatography separations. Oligonucleotide purifications were performed on PolyPak II reverse phase cartridges (Glen Research). Oligonucleotides were freeze-dried on a Savant Speed Vac concentrator SVC $100 \mathrm{H}$ from Thermo Scientific.

\subsection{Synthesis of spermine synthon}

\subsection{1. $N^{1}, N^{2}, N^{3}, N^{4}$-Tetra(trifluoroacetyl)spermine (1)}

Spermine $(10 \mathrm{~g}, 50 \mathrm{mmol})$ and DMAP $(37.2 \mathrm{~g}, 300 \mathrm{mmol})$ were stirred in DCM $(200 \mathrm{~mL})$ under argon and cooled to $0{ }^{\circ} \mathrm{C}$. Trifluoroacetic anhydride $(52.3 \mathrm{~g}, 250 \mathrm{mmol})$ in DCM $(150 \mathrm{~mL})$ was added dropwise over $1.5 \mathrm{~h}$. The ice bath was then removed and the mixture was allowed to stir at rt for $5.5 \mathrm{~h}$. The reaction was quenched by the addition of dist. $\mathrm{H}_{2} \mathrm{O}(350 \mathrm{~mL})$. The aqueous layer was separated and extracted with DCM $(2 \times 200 \mathrm{~mL})$. Organic phases were combined, dried for $15 \mathrm{~min}\left(\mathrm{MgSO}_{4}\right)$, filtered and concentrated in vacuo to give a colourless oil $(39.4 \mathrm{~g})$ containing residual DMAP. The crude product was used without further purification for the synthesis of $\mathbf{3}$. The pure product could be obtained by salinification for analyses: the oil was dissolved in ethanol by heating with a heat gun. $\mathrm{HCl}(37 \%)$ was added and the mixture was cooled to $0{ }^{\circ} \mathrm{C}$. The product was filtered, washed with dist. $\mathrm{H}_{2} \mathrm{O}$ and dried overnight in vacuo before analyses. Analyses were performed on the saline product.

White powder, mp: $114 \pm 1{ }^{\circ} \mathrm{C}$; IR: $v=3317.8(\mathrm{~N}-\mathrm{H}), v=1734.5$ $(\mathrm{C}=0), \quad v=1677.8 \quad(\mathrm{C}=0), \quad \delta=1561.4 \quad(\mathrm{~N}-\mathrm{H}) \quad \mathrm{cm}^{-1} ; \quad{ }^{1} \mathrm{H} \quad \mathrm{NMR}$ (400 MHz, DMSO) $\delta 9.51$ and $9.41(2 \mathrm{t}, J=5.6 \mathrm{~Hz}, 2 \mathrm{H}), 3.40-3.36$ (br m, 8H), 3.25-3.18 (m, 4H), 1.86-1.72 (m, 4H), 1.63-1.43 (br $\mathrm{m}, 4 \mathrm{H}) ;{ }^{13} \mathrm{C}$ NMR $(400 \mathrm{MHz}$, DMSO) $\delta 156.13-156.01,155.76-$ 155.65 (2C), 155.21, 154.86 (2C), 120.16-119.77, 117.30-116.88, 
114.43-114.02, 111.57-111.17 (4C), 46.81-46.70, 46.06-45.88, 44.69-44.64, 44.24 $\left(\mathrm{CH}_{2}, 4 \mathrm{C}\right) 36.87,36.45\left(\mathrm{CH}_{2}, 2 \mathrm{C}\right), 27.74,25.83$ $\left(\mathrm{CH}_{2}, 2 \mathrm{C}\right), 25.43-25.15,23.56-23.34\left(\mathrm{CH}_{2}, 2 \mathrm{C}\right)$; LC-MS, $\mathrm{m} / z$ : calcd for $\mathrm{C}_{18} \mathrm{H}_{22} \mathrm{~F}_{12} \mathrm{~N}_{4} \mathrm{O}_{4}$ : 586.1, found: $587.0[\mathrm{M}+\mathrm{H}]^{+}$.

\subsection{2. $N^{1}, N^{4}$-Bis(tert-butoxycarbonyl)- $N^{2}, N^{3}$-bis(trifluoroacetyl) spermine (3)}

Di(tert-butyl) dicarbonate $(33.7 \mathrm{~g}, 150 \mathrm{mmol})$ in DCM $(100 \mathrm{~mL})$ was added dropwise to a suspension of the crude product 1 (39.4 g) and DMAP (12.4 g, $100 \mathrm{mmol})$ in DCM $(180 \mathrm{~mL})$. During the reaction, a gas release was observed and the suspension solubilised. The reaction was stirred overnight at rt. $1 \mathrm{M}$ aqueous $\mathrm{NH}_{4} \mathrm{Cl}$ $(200 \mathrm{~mL})$ was added; the organic layer was separated and washed with $1 \mathrm{M} \mathrm{NH}_{4} \mathrm{Cl}(2 \times 200 \mathrm{~mL})$. The organic phase was then dried for $15 \mathrm{~min}\left(\mathrm{MgSO}_{4}\right)$, filtered off and concentrated under reduced pressure. The crude product was recrystallised under stirring in methanol $(60 \mathrm{~mL})$, cooled to $4{ }^{\circ} \mathrm{C}$ for $1 \mathrm{~h}$, filtered off, washed with cold methanol and dried in vacuo overnight. White powder: $24.4 \mathrm{~g}$, 84\% (steps 1, 2 and 3), mp: $141 \pm 1{ }^{\circ} \mathrm{C}$; IR: $v=3344.8(\mathrm{~N}-\mathrm{H})$, $v=1693.4(\mathrm{C}=\mathrm{O}), \quad v=1675.5(\mathrm{C}=\mathrm{O}), \delta=1519.9(\mathrm{~N}-\mathrm{H}) \mathrm{cm}^{-1} ;{ }^{1} \mathrm{H}$ NMR $\left(400 \mathrm{MHz}, \mathrm{CDCl}_{3}\right) \delta 5.01(\mathrm{br}, 1 \mathrm{H}), 4.79(\mathrm{br}, 1 \mathrm{H}), 3.40-3.34$ (br m, 8H), 3.12-3.05 (m, 4H), 1.79-1.68 (m, 4H), 1.56-1.54 (br $\mathrm{m}, 4 \mathrm{H}), 1.381(\mathrm{~s}, 18 \mathrm{H}) ;{ }^{13} \mathrm{C}$ NMR $\left(400 \mathrm{MHz}, \mathrm{CDCl}_{3}\right) \delta 157.39-$ $157.33, \quad 157.2-157.17, \quad 157.03-156.98,156.85-156.82 \quad$ (2C), 156.24 (2C), 120.89, 118.05, 115.19, 112.31 (2C), 79.70-79.60, $79.42-79.34$ (2C), 47.15, 46.43-46.36, 45.49, 44.43-44.38 (4C), 37.91-37.67 (2C), 29.90-29.76, 27.65-27.58 (2C), 28.51-28.45 (6C), 25.99-25.92, 24.15-24.06 (2C); Anal. Calcd for $\mathrm{C}_{24} \mathrm{H}_{40} \mathrm{~F}_{6} \mathrm{~N}_{4} \mathrm{O}_{6}$ : C, 48.48; H, 6.78; N, 9.42. Found: C, 48.35; H, 6.87; N, 9.25. LC-MS, $\mathrm{m} / z$ : calcd for $\mathrm{C}_{24} \mathrm{H}_{40} \mathrm{~F}_{6} \mathrm{~N}_{4} \mathrm{O}_{6}$ : 594.3, found: $617.2[\mathrm{M}+\mathrm{Na}]^{+}$.

\subsection{3. $N^{1}, N^{4}$-Bis(trifluoroacetyl)spermine (4)}

To a suspension of spermine 3 (596 mg, $1 \mathrm{mmol}, 1$ equiv) in solution in DCM $(5 \mathrm{~mL})$ were added slowly under stirring $2 \mathrm{~mL}$ of trifluoroacetic acid. Two phases appeared. After $30 \mathrm{~min}$ of reaction, the mixture was evaporated to provide an orange oil $(1.31 \mathrm{~g})$. The product was then gently washed and triturated in DCM $(3 \times 2 \mathrm{~mL})$ and diethyl ether $(3 \times 2 \mathrm{~mL})$ to eliminate residual TFA. Organic solvents were then removed with a pasteur pipette. The product was then dried by evaporation under reduced pressure. To provide 4 as a free amine, the product $(552 \mathrm{mg})$ dissolved in $\mathrm{MeOH}(3.5 \mathrm{~mL})$ was passed through an ion exchange column (Dowex $21 \mathrm{KCl}$ exchange anion, $3.6 \mathrm{~g}$ ) that had been previously prepared by successive elution of an aqueous solution of $\mathrm{NaOH} 1 \mathrm{M}(300 \mathrm{~mL})$, distilled water (until $\mathrm{pH} 7$ ) and methanol $(50 \mathrm{~mL}$ ). The product was then eluted with methanol and evaporated under reduced pressure to yield 4 as a pale yellow oil (324 mg, $55 \%)$. ${ }^{1} \mathrm{H}$ NMR $(300 \mathrm{MHz}$, $\left.\mathrm{CDCl}_{3}\right) \delta 9.48(\mathrm{br}, 2 \mathrm{H}), 3.47-3.43(\mathrm{t}, J=6 \mathrm{~Hz}, 4 \mathrm{H}), 2.84-2.80(\mathrm{t}$, $J=5.4 \mathrm{~Hz}, 4 \mathrm{H}), 2.61-2.56(\mathrm{t}, J=6.3 \mathrm{~Hz}, 4 \mathrm{H}), 1.72-1.65(\mathrm{~m}, 4 \mathrm{H})$, $1.50-1.46(\mathrm{~m}, 4 \mathrm{H})$.

\subsection{4. $N^{\mathbf{1}}, N^{4}$-Bis(tert-butoxycarbonyl)spermine (5)}

To a suspension of $\mathbf{3}(24.4 \mathrm{~g}, 41 \mathrm{mmol})$ in methanol $(130 \mathrm{~mL})$ was added, at rt, a $10 \mathrm{M}$ aqueous solution of $\mathrm{NaOH}(40 \mathrm{~mL})$. The reaction was allowed to proceed overnight under stirring. The following day, the mixture was concentrated under reduced pressure to a third of its initial volume and supplemented with $1 \mathrm{M}$ aqueous $\mathrm{NaOH}(65 \mathrm{~mL})$. DCM $(150 \mathrm{~mL})$ was added; the aqueous layer was separated and extracted with DCM $(2 \times 150 \mathrm{~mL})$. The organic layers were combined, dried for $15 \mathrm{~min}\left(\mathrm{MgSO}_{4}\right)$, filtered and concentrated under reduced pressure. The pure product was obtained by precipitation with heptane $(200 \mathrm{~mL})$ and dried in vacuo overnight before analyses. White powder: $15.5 \mathrm{~g}, 94 \%, \mathrm{mp}$ : $94 \pm 1^{\circ} \mathrm{C}$; IR: $v=3344.8(\mathrm{~N}-\mathrm{H}), v=1693.1(\mathrm{C}=\mathrm{O}), \delta=1522.1(\mathrm{~N}-\mathrm{H}) \mathrm{cm}^{-1} ;{ }^{1} \mathrm{H}$ $\operatorname{NMR}\left(300 \mathrm{MHz}, \mathrm{CDCl}_{3}\right) \delta 5.16(\mathrm{br}, 2 \mathrm{H}), 3.20-3.14(\mathrm{q}, J=8 \mathrm{~Hz}, 4 \mathrm{H})$, $2.66-2.62(\mathrm{t}, J=8.8 \mathrm{~Hz}, 4 \mathrm{H}), 2.60-2.56(\mathrm{t}, J=8 \mathrm{~Hz}, 4 \mathrm{H}), 1.66-1.57$ (quintuplet, $J=8.8 \mathrm{~Hz}, 4 \mathrm{H}$ ), $1.52-1.48$ (br m, 4H), 1.41 (s, 18H). ${ }^{13} \mathrm{C}$ NMR (400 MHz, CDCl3) $\delta 156.21$ (2C), 78.90 (2C), 49.78 (2C), 47.72 (2C), 39.24 (2C), 29.97 (2C), 28.52 (6C), 27.87 (2C); Anal. Calcd for $\mathrm{C}_{20} \mathrm{H}_{42} \mathrm{~N}_{4} \mathrm{O}_{4}$ : C, 59.67; H, 10.52; N, 13.92. Found: C, 59.53; $\mathrm{H}, 10.44 ; \mathrm{N}, 13.76$. LC-MS $\mathrm{m} / \mathrm{z}$ : calcd for $\mathrm{C}_{20} \mathrm{H}_{42} \mathrm{~N}_{4} \mathrm{O}_{4}$ : 402.3, found: $403.3[\mathrm{M}+\mathrm{H}]^{+}$.

\subsubsection{4-Nitrophenethyl 4-nitrophenyl carbonate (6)}

4-Nitrophenyl chloroformate $(21.8 \mathrm{~g}, 105 \mathrm{mmol})$ in DCM $(140 \mathrm{~mL})$ was cooled to $0{ }^{\circ} \mathrm{C}$ under stirring. A mixture of 4-nitrophenethyl alcohol $(16.9 \mathrm{~g}, 100 \mathrm{mmol})$ and pyridine $(9 \mathrm{~mL}$, $111 \mathrm{mmol})$ in DCM $(60 \mathrm{~mL})$ was added dropwise at $0{ }^{\circ} \mathrm{C}$ within $2 \mathrm{~h}$. The reaction was then allowed to warm to rt until consumption of all the 4-nitrophenethyl alcohol as revealed by TLC (AcOEt/cyclohexane $1: 1)$. The reaction mixture was washed by $1 \mathrm{M} \mathrm{Na}_{2} \mathrm{CO}_{3}(200 \mathrm{~mL})$ and by dist. $\mathrm{H}_{2} \mathrm{O}(2 \times 200 \mathrm{~mL})$. The organic layer was then dried for $15 \mathrm{~min}\left(\mathrm{MgSO}_{4}\right)$, filtered and evaporated under reduced pressure. Precipitation with diethyl ether $(300 \mathrm{~mL})$ and subsequent cold diethyl ether washes yielded 6. Off-white powder: $25.4 \mathrm{~g}, 76.5 \%$, mp: $104 \pm 1^{\circ} \mathrm{C}$; IR: $v=3084.9(\mathrm{Ar} \quad \mathrm{C}-\mathrm{H}), \quad v=1766.3(\mathrm{C}=\mathrm{O})$, $v=1518.7\left(\mathrm{NO}_{2}\right.$ as $), \quad v=1346.7\left(\mathrm{NO}_{2} \mathrm{sym}\right) \mathrm{cm}^{-1} ;{ }^{1} \mathrm{H} \quad \mathrm{NMR}$ $\left(400 \mathrm{MHz}, \mathrm{CDCl}_{3}\right) \delta 8.25-8.15(\mathrm{~m}, 4 \mathrm{H}), 7.44-7.29(\mathrm{~m}, 4 \mathrm{H}), 4.54-$ $4.51(\mathrm{t}, J=6.8 \mathrm{~Hz}, 2 \mathrm{H}), 3.19-3.13(\mathrm{t}, J=6.6 \mathrm{~Hz}, 2 \mathrm{H}) ;{ }^{13} \mathrm{C}$ NMR (200 MHz, $\left.\mathrm{CDCl}_{3}\right) \delta 155.45$ (1C), 152.38 (1C), 147.17 (1C), 145.51 (1C), $144.79(1 \mathrm{C}), 129.97(\mathrm{C}-\mathrm{H}, 2 \mathrm{C}), 125.38(\mathrm{C}-\mathrm{H}, 2 \mathrm{C}), 123.95(\mathrm{C}-\mathrm{H}$, 2C), $121.84(\mathrm{C}-\mathrm{H}, 2 \mathrm{C}), 68.63\left(\mathrm{CH}_{2}, 1 \mathrm{C}\right), 34.80\left(\mathrm{CH}_{2}, 1 \mathrm{C}\right)$; Anal. Calcd for $\mathrm{C}_{15} \mathrm{H}_{12} \mathrm{~N}_{2} \mathrm{O}_{7}$ : C, 54.22; $\mathrm{H}, 3.64 ; \mathrm{N}, 8.43$. Found: $\mathrm{C}, 54.18 ; \mathrm{H}, 3.6$; $\mathrm{N}$, 8.5. HRMS (ESI) $m / z$ : calcd for $\mathrm{C}_{15} \mathrm{H}_{12} \mathrm{~N}_{2} \mathrm{O}_{7}$ : 332.064, found: 332.064 .

\subsection{6. $N^{1}, N^{4}$-Bis(tert-butoxycarbonyl)- $N^{2}, N^{3}-$ bis [2-(4- nitrophenyl)ethoxycarbonyl]spermine (7)}

To $5(15.5 \mathrm{~g}, 39 \mathrm{mmol})$ in DCM $(115 \mathrm{~mL})$ were added at $\mathrm{rt}$, under stirring 6 (26.9 g, $81 \mathrm{mmol})$ and DMAP $(4.9 \mathrm{~g}, 40 \mathrm{mmol})$. The reaction mixture was allowed to stir overnight. $1 \mathrm{M}$ aqueous $\mathrm{Na}_{2} \mathrm{CO}_{3}$ $(200 \mathrm{~mL})$ was added and salts appeared in the aqueous layer. The aqueous phase was diluted with dist. $\mathrm{H}_{2} \mathrm{O}(100 \mathrm{~mL})$. The organic layer was separated, washed with $1 \mathrm{M} \mathrm{Na}_{2} \mathrm{CO}_{3}(2 \times 200 \mathrm{~mL})$, dried for $15 \mathrm{~min}\left(\mathrm{MgSO}_{4}\right)$, filtered off and evaporated under reduced pressure. Pure product 7 was obtained by precipitation in diethyl ether $(300 \mathrm{~mL})$, filtered off, washed with cold ether and dried overnight in vacuo. White powder: $29.4 \mathrm{~g}, 97 \%$, mp: $134 \pm 1{ }^{\circ} \mathrm{C}$; IR: $v=3349.7$ $(\mathrm{N}-\mathrm{H}), v=1694.1(\mathrm{C}=\mathrm{O}), v=1519.2\left(\mathrm{NO}_{2} \mathrm{as}\right), v=1345.7\left(\mathrm{NO}_{2}\right.$ sym) $\mathrm{cm}^{-1} ;{ }^{1} \mathrm{H}$ NMR (400 MHz, $\left.\mathrm{CDCl}_{3}\right) \delta 8.11-8.09$ (d, $J=8.4 \mathrm{~Hz}$, $4 \mathrm{H}), 7.34-7.32(\mathrm{~m}, 4 \mathrm{H}), 5.11(\mathrm{br}, 1 \mathrm{H}),, 4.60(\mathrm{br}, 1 \mathrm{H}), 4.30-4.27(\mathrm{t}$, $J=6.6 \mathrm{~Hz}, 4 \mathrm{H}), 3.19-2.93(\mathrm{~m}, 16 \mathrm{H}), 1.58-1.53(\mathrm{~m}, 4 \mathrm{H}), 1.37(\mathrm{~s}$, $18 \mathrm{H}) ;{ }^{13} \mathrm{C}$ NMR $\left(400 \mathrm{MHz}, \mathrm{CDCl}_{3}\right) \delta 156.39-155.85$ (4C), 146.93 (2C) 146.15 (2C), 129.85 (4C), 123.76 (4C), 79.47-79.07 (2C), 64.92 (2C), 47.11, 46.53 (2C), 44.52 (2C) 38.13, 37.43 (2C), 35.49 (2C), 29.22 (2C), 28.51 (6C), 25.86-25.22 (2C); Anal. Calcd for $\mathrm{C}_{38} \mathrm{H}_{56} \mathrm{~N}_{6} \mathrm{O}_{12}$ : C, 57.85; H, 7.15; N, 10.65. Found: C, 57.68; H, 7.35; $\mathrm{N}, 10.60$. HRMS (ESI) $m / z$ : calcd for $\mathrm{C}_{38} \mathrm{H}_{56} \mathrm{~N}_{6} \mathrm{O}_{12}$ : 788.396, found: 788.396 .

\subsection{7. $N^{1}, N^{4}$-Bis(monomethoxytrityl)- $N^{2}, N^{3}$-bis[2-(4-nitro phenyl)ethoxycarbonyl]spermine (8)}

To a stirred solution of $7(29.4 \mathrm{~g}, 37 \mathrm{mmol})$ in DCM $(180 \mathrm{~mL})$ cooled at $0{ }^{\circ} \mathrm{C}$ was slowly added trifluoroacetic acid $(44.4 \mathrm{~g}$, $390 \mathrm{mmol}$ ) over $5 \mathrm{~min}$. The reaction was next allowed to warm up to rt within $2 \mathrm{~h}$. The reaction mixture was evaporated under reduced pressure. The crude deprotected product containing remaining trifluoroacetic acid was then dissolved in DCM $(100 \mathrm{~mL})$ and cooled to $0{ }^{\circ} \mathrm{C}$ under stirring. A large excess of triethylamine $(72.6 \mathrm{~g}$, $720 \mathrm{mmol})$ in DCM $(50 \mathrm{~mL})$ was added dropwise. The ice bath was then removed and 4-monomethoxytrityl chloride $(48.2 \mathrm{~g}$, $156 \mathrm{mmol})$ in DCM $(100 \mathrm{~mL})$ was rapidly added at rt. After $30 \mathrm{~min}$, 
$1 \mathrm{M}$ aqueous $\mathrm{Na}_{2} \mathrm{CO}_{3}(150 \mathrm{~mL})$ was poured into the reaction mixture. The aqueous phase was separated and extracted with DCM $(2 \times 150 \mathrm{~mL})$. Combined organic layers were dried for $15 \mathrm{~min}$ $\left(\mathrm{MgSO}_{4}\right)$, filtered and evaporated to dryness. The crude product (yellow oil, $60 \mathrm{~g}$ ), was purified by flash column chromatography on silica gel using AcOEt/cyclohexane: $1: 1$ as eluent to afford $\mathbf{8}$, dried overnight in vacuo. White foam $(33.5 \mathrm{~g}, 79 \%)$; IR: $v=1689.9(C=0)$, $v=1517.8\left(\mathrm{NO}_{2}\right.$ as $), \quad v=1344.1 \quad\left(\mathrm{NO}_{2} \mathrm{sym}\right) \mathrm{cm}^{-1} ;{ }^{1} \mathrm{H} \quad \mathrm{NMR}$ $\left(400 \mathrm{MHz}, \mathrm{CDCl}_{3}\right) \delta 8.15-8.04(\mathrm{~m}, 4 \mathrm{H}), 7.43-7.41(\mathrm{~d}, J=7.6 \mathrm{~Hz}, 8 \mathrm{H})$, 7.33-7.32 (d, $J=8.4 \mathrm{~Hz}, 4 \mathrm{H}), 7.28-7.23(\mathrm{~m}, 12 \mathrm{H}), 7.18-7.13(\mathrm{~m}$, $4 \mathrm{H}), 6.79-6.75$ (m, 4H), 4.25-4.22 (br m, 4H), $3.74(\mathrm{~s}, 6 \mathrm{H}), 3.27-$ 2.94 (br m, 12H), 2.05 (br m, 4H), $1.66-1.30$ (br m, 8H); ${ }^{13} \mathrm{C} \mathrm{NMR}$ (400 MHz, CDCl3) $\delta$ 158.04-157.94 (2C), 155.90 (2C), 146.92 (4C), 146.57, 146.41, 146.22 (4C), 138.48-138.29 (, 2C), 129.85 (4C), 128.63 (12C), 127.97 (8C), 126.45-126.26 (4C), $123.79(4 \mathrm{C}), 113.27$ (4C), 70.30 (2C), 64.78 (2C), 55.33 (2C), 47.24-46.46 (2C), 45.51 (2C), 41.36-40.87 (2C), 35.54 (2C), 30.08-29.26 (2C), 25.92-25.51 (2C); HRMS (ESI) $m / z$ : calcd for $\mathrm{C}_{68} \mathrm{H}_{72} \mathrm{~N}_{6} \mathrm{O}_{10}: 1132.531$, found: 1132.532 .

\subsection{8. $N^{1}$-(Monomethoxytrityl)- $N^{2}, N^{3}$-bis[2-(4- nitrophenyl)ethoxycarbonyl]spermine (9)}

To a stirred solution of $\mathbf{8}(33.5 \mathrm{~g}, 30 \mathrm{mmol})$ in DCM $(200 \mathrm{~mL})$ was poured trifluoroacetic acid $(6.8 \mathrm{~g}, 59 \mathrm{mmol})$ in DCM $(200 \mathrm{~mL})$ at rt. The mixture immediately turned orange which went intensifying in the course of the reaction. Reaction was monitored by TLC until the orange color of the mono-trityl protected product spot appeared nearly a half as intense as the color of the bis-trityl protected product spot ( 1 h reaction time, TLC eluent: $\mathrm{DCM} / \mathrm{MeOH} / \mathrm{NH}_{3}, 90: 10: 1$, staining of the plate: $5 \% \mathrm{PMA} / \mathrm{EtOH}) .1 \mathrm{M}$ aqueous $\mathrm{Na}_{2} \mathrm{CO}_{3}(400 \mathrm{~mL}$ ) was then added to quench the reaction. The aqueous layer was extracted by DCM $(2 \times 200 \mathrm{~mL})$. The combined organic phase was dried for $15 \mathrm{~min}\left(\mathrm{MgSO}_{4}\right)$, filtered off and evaporated under reduced pressure. The crude product (yellow oil, $36 \mathrm{~g}$ ) was purified by flash column chromatography on silica gel using a 90:10:0-80:20:6 gradient of $\mathrm{DCM} / \mathrm{MeOH} / \mathrm{NH}_{3}$ (2 $\mathrm{M}$ in methanol), which yielded the pure product $(6.8 \mathrm{~g}, 8 \%)$ as a pale yellow foam. The reaction was reiterated on unreacted fractions of 8 until the global yield reached $62 \%$ of the involved material. In one step, yield of the reaction could be levelled up to $37 \%$ (10 mmol scale, 2.1 equiv of trifluoroacetic acid, 55 min reaction time). Pale yellow foam: $16.0 \mathrm{~g}, 62 \% ;{ }^{1} \mathrm{H}$ NMR $\left(400 \mathrm{MHz}, \mathrm{CDCl}_{3}\right)$ $\delta 8.16-8.07$ (dd, $\left.J_{1}=29.2 \mathrm{~Hz}, J_{2}=8 \mathrm{~Hz}, 4 \mathrm{H}\right), 7.47-7.45(\mathrm{~d}, J=8 \mathrm{~Hz}$, $4 \mathrm{H}), 7.37-7.25(\mathrm{~m}, 10 \mathrm{H}), 7.20-7.17(\mathrm{~m}, 2 \mathrm{H}), 6.83-6.81(\mathrm{~m}, 2 \mathrm{H})$, $4.35-4.29$ (dt, $\left.J_{1}=18.8 \mathrm{~Hz}, J_{2}=6.4 \mathrm{~Hz}, 4 \mathrm{H}\right), 3.77(\mathrm{~s}, 3 \mathrm{H}), 3.31-2.97$ (m, 12H), 2.74-2.63(m, 2H), 2.10 (br m, 2H), 1.71 (br m, 2H), 1.601.27 (br m, 8H); ${ }^{13} \mathrm{C}$ NMR (400 MHz, CDCl3) $\delta 157.96-157.85$ (1C, 1), 155.85 (2C), 146.87-146.82 (2C), 146.49, 146.32, 146.18 (4C), 138.40-138.19 (1C), 129.83 (4C), 128.54 (6C), 127.88 (4C), 126.35126.18 (2C), 123.70 (4C), 113.18 (2C), 70.45 (1C), 64.95-64.75 (2C), 55.24 (1C), 47.17-47.08, 46.53-46.37, 45.44 (6C), 41.27-40.78 (1C), 35.46 (2C), 31.98 (1C), 30.45-29.16 (1C), 25.83-25.38 (2C); MS (ESI), $m / z$ : calcd for $\mathrm{C}_{48} \mathrm{H}_{56} \mathrm{~N}_{6} \mathrm{O}_{9}: 860.99$, found: 861.40, $[\mathrm{M}+\mathrm{H}]^{+}$.

\subsection{9. $N^{1}$-(9-Fluorenylmethoxycarbonylthiourea)- $N^{2}, N^{3}$-bis[2- (4-nitrophenyl)ethoxycarbonyl]- $N^{4}$ - (monomethoxytrityl)spermine (10)}

To a stirred solution of Fmoc-isothiocyanate $(6.4 \mathrm{~g}, 23 \mathrm{mmol})$ in DCM $(300 \mathrm{~mL})$ cooled at $0{ }^{\circ} \mathrm{C}$ was added $\mathbf{9}(12.7 \mathrm{~g}, 15 \mathrm{mmol})$ under argon. The reaction occurred instantaneously as revealed by TLC (eluent: AcOEt/cyclohexane, 1:1, staining agent: PMA 5\% in EtOH). The ice bath was then removed and the reaction mixture was evaporated under reduced pressure. The crude product was purified by flash column chromatography on silica gel (eluent: AcOEt/cyclohexane, 1:1), which afforded the pure product 10 , dried overnight in vacuo. White foam: $13.9 \mathrm{~g}, 82 \%$; IR: $v=3294.0(\mathrm{NH}), v=1692.7(\mathrm{C}=\mathrm{O})$, $v=1518.0\left(\mathrm{NO}_{2}\right.$ as $), 1344.7\left(\mathrm{NO}_{2} \mathrm{sym}\right) \mathrm{cm}^{-1} ;{ }^{1} \mathrm{H}$ NMR $(400 \mathrm{MHz}$,
$\left.\mathrm{CDCl}_{3}\right) \delta 9.89$ (br s, $\left.1 \mathrm{H}\right), 9.59$ (br s, $\left.1 \mathrm{H}\right), 8.10-8.04(\mathrm{~m}, 4 \mathrm{H}), 7.77-$ $7.75(\mathrm{~d}, J=7.6 \mathrm{~Hz}, 2 \mathrm{H}), 7.54-7.52(\mathrm{~d}, J=7.6 \mathrm{~Hz}, 2 \mathrm{H}), 7.42-7.38(\mathrm{~m}$, $6 \mathrm{H}$,), 7.33-7.28 (m, 8H), 7.26-7.23 (m, 4H), 7.17-7.14 (br m, 2H), 6.79-6.76 (br m, 2H), 4.47-4.46 (d, J=6.8 Hz, 2H), 4.34-4.20 (m, $5 \mathrm{H}), 3.74(\mathrm{~s}, 3 \mathrm{H}), 3.64-3.52$ (br m, 2H), 3.26-2.95 (br m, $12 \mathrm{H})$, 2.07-2.04 (br m, 2H), 1.82-1.33 (br m, 8H); ${ }^{13} \mathrm{C} \mathrm{NMR} \mathrm{(400} \mathrm{MHz,}$ $\mathrm{CDCl} 3) \delta 179,24$ (1C), 158.01-157.91 (1C), 155.89 (2C), 156.59, 152.81-152.46, 148.96 (1C), 146.93-146.89 (2C), 146.55, 146.37, 146.20, 146.03, (4C), 143.03 (2C), 141.43 (2C), 138.46 (1C), 129.83 $(\mathrm{CH}, 4 \mathrm{C}), 128.60(\mathrm{CH}, 6 \mathrm{C}), 128.23(\mathrm{CH}, 2 \mathrm{C}), 127.94-127.86(\mathrm{CH}, 4 \mathrm{C})$, $127.39(\mathrm{CH}, 2 \mathrm{C}), 126.42-126.22(\mathrm{CH}, 2 \mathrm{C}), 125.01(\mathrm{CH}, 1 \mathrm{C}), 123.79-$ $123.77(\mathrm{CH}, 4 \mathrm{C}), 120.35(\mathrm{CH}, 2 \mathrm{C}), 113.24(\mathrm{CH}, 2 \mathrm{C}), 70.51(1 \mathrm{C})$, 68.49-68.37 $\left(\mathrm{CH}_{2}, 1 \mathrm{C}\right), 65.03-64.77\left(\mathrm{CH}_{2}, 2 \mathrm{C}\right), 55.31\left(\mathrm{CH}_{3}, 1 \mathrm{C}\right)$, $46.42,46.81,47.14,46.42\left(\mathrm{CH}_{2}, 2 \mathrm{C}\right), 46.63(\mathrm{CH}, 1 \mathrm{C}), 45.51\left(\mathrm{CH}_{2}\right.$, $1 \mathrm{C}), 44.65\left(\mathrm{CH}_{2}, 1 \mathrm{C}\right), 42.81-43.02\left(\mathrm{CH}_{2}, 1 \mathrm{C}\right), 41.33-40.85\left(\mathrm{CH}_{2}, 1 \mathrm{C}\right)$, $35.50\left(\mathrm{CH}_{2}, 2 \mathrm{C}\right), 30.07,29.22,27.48-27.05,25.87-25.44\left(\mathrm{CH}_{2}, 4 \mathrm{C}\right)$; HRMS (ESI) $m / z$ : calcd for $\mathrm{C}_{64} \mathrm{H}_{67} \mathrm{~N}_{7} \mathrm{O}_{11} \mathrm{~S}: 1141.46$, found: 1142.47 $[\mathrm{M}+\mathrm{H}]^{+}$

\subsubsection{0. $\boldsymbol{N}^{\mathbf{1}}$-(Monomethoxytrityl)diaminooctane (11)}

To a solution of diaminooctane $(7.2 \mathrm{~g}, 50 \mathrm{mmol})$ dissolved in DCM $(70 \mathrm{~mL})$ was added dropwise at $0{ }^{\circ} \mathrm{C}$, under stirring, a solution of 4monomethoxytrityl chloride $(3.3 \mathrm{~g}, 10 \mathrm{mmol})$ dissolved in DCM $(200 \mathrm{~mL})$. The reaction was then allowed to warm up to room temperature for $1.25 \mathrm{~h}$. An aqueous solution of $\mathrm{Na}_{2} \mathrm{CO}_{3} 1 \mathrm{M}(200 \mathrm{~mL})$ was added. The aqueous phase was extracted by DCM $(2 \times 100 \mathrm{~mL})$. Organic phases were pooled, dried on $\mathrm{MgSO}_{4}$, filtrated and evaporated under reduced pressure. The crude product $(6.8 \mathrm{~g})$ was purified by flash chromatography (eluent: $\mathrm{DCM} / \mathrm{MeOH} / \mathrm{Et}_{3} \mathrm{~N}$ : 90:10:2). The pure product 11 was obtained as a white oil (2.7 g, 65\%). ${ }^{1} \mathrm{H}$ NMR $\left(400 \mathrm{MHz}, \mathrm{CDCl}_{3}\right) \delta 7.46-7.43(\mathrm{~m}, 4 \mathrm{H}), 7.37-7.33(\mathrm{~m}$ 2H), 7.26-7.22 (m, 4H), 7.17-7.12 (m, 2H), 6.80-6.76 (m, 2H), 3.75 $(\mathrm{s}, 3 \mathrm{H}), 2.69-2.66(\mathrm{t}, J=7.1 \mathrm{~Hz}), 2.11-2.07(\mathrm{t}, J=7 \mathrm{~Hz}, 2 \mathrm{H}), 1.48-$ $1.40(\mathrm{~m}, 4 \mathrm{H}), 1.30-1.21(\mathrm{~m}, 8 \mathrm{H}) ;{ }^{13} \mathrm{C}$ NMR $(400 \mathrm{MHz}, \mathrm{CDCl} 3) \delta$ 157.93 (1C), 146.81 (2C), 138.75 (1C), 129.97 (2C), 128.75 (4C), 127.86 (4C), 126.22 (2C), 113.19 (2C), 70.53 (1C), 55.34 (1C), 43.75 (1C), 42.03 (1C), 33.04 (1C), 31.06 (1C), 29.76 (1C), 29.55 (1C), $27.50(1 \mathrm{C}), 26.98(1 \mathrm{C})$.

\subsection{General procedure for the synthesis of spermine oligomers on solid support}

\subsubsection{Amino linker introduction on dT-CPG}

A $1 \mu \mathrm{mol}$ scale dT-CPG column was automatically detritylated on an Expedite synthesizer by a solution of TCA in DCM (Glen Research reagent). DMT fraction was collected and diluted in 3\% TCA/DCM solution $(100 \mathrm{~mL})$ and its absorbance at $503 \mathrm{~nm}$ was measured. The column was then manually rinsed with DCM $(3 \times 1 \mathrm{~mL})$ and flushed under argon. A solution of CDI ( $32 \mathrm{mg}, 200 \mu \mathrm{mol})$ in anhydrous DCM $(1 \mathrm{~mL})$ was percolated trough for $1 \mathrm{~h}$. The reagent was then flushed out of the system; the cartridge was rinsed with DCM $(2 \times 1 \mathrm{~mL})$ and flushed under argon. A solution of $11(50 \mathrm{mg}$, $120 \mu \mathrm{mol})$ and triethylamine $(12.3 \mathrm{mg}, 120 \mu \mathrm{mol})$ in anhydrous DCM $(1 \mathrm{~mL})$ were percolated through the column for $2 \mathrm{~h}$ and the reagents were flushed out of the system. The column was washed with DCM $(3 \times 1 \mathrm{~mL})$ and flushed under argon. Unreacted sites were capped by $\mathrm{Ac}_{2} \mathrm{O} / \mathrm{NMI}$ on a synthesizer with a prolonged capping cycle of 6 min. The MMT final protecting group was detritylated on the synthesizer with the following protocol: a TCA/DCM solution (Glen Research reagent) was passed through the column during $15 \mathrm{~s}$, the reaction was allowed to proceed for $3 \mathrm{~min}$ and the cycle was repeated four times (16 min). The column was then rinsed with acetonitrile (two washes) and flushed under argon. MMT fraction was collected and diluted in 3\% TCA/DCM solution $(100 \mathrm{~mL})$ and its absorbance at $478 \mathrm{~nm}$ was measured. Yields of amino-linker coupling step were calculated on MMT absorbance at $478 \mathrm{~nm}$ and 
DMT absorbance at $503 \mathrm{~nm}$ ratios, corrected by a UV ratio factor (UVRF) of $1.36\left(E_{\mathrm{DMT}}=76 \mathrm{~mL} \mathrm{~cm}{ }^{-1} \mu \mathrm{mol}^{-1}, E_{\mathrm{MMT}}=56 \mathrm{~mL} \mathrm{~cm} \mathrm{~cm}^{-1}\right.$ $\left.\mu \mathrm{mol}^{-1}\right) .{ }^{22}$ Amino-linker coupling yields were comprised between $75 \%$ and $80 \%$.

\subsubsection{Spermines oligomerisation on amino-modified dT-CPG}

A 0.4 M solution of DIPEA in DCM $(1 \mathrm{~mL})$ was passed through the column. Before that, $\mathbf{1 0}(23.5 \mathrm{mg}, 20 \mu \mathrm{mol})$ and EDC (17 mg, $88 \mu \mathrm{mol})$ were dried for $30 \mathrm{~min}$ in vacuo. 10 and EDC were then mixed and dissolved in $0.4 \mathrm{M}$ DIPEA $(220 \mu \mathrm{L}, 88 \mu \mathrm{mol})$ before being percolated through the column for $4 \mathrm{~h}$. The reagents were flushed out and the column was rinsed by DCM $(3 \times 1 \mathrm{~mL})$. The active sites that had not reacted during the process were capped manually with $0.5 \mathrm{~mL}$ of acetic anhydride (cap Mix A, Glen Research)/ $0.5 \mathrm{~mL} \mathrm{~N}$-methylimidazole (cap mix B, Glen Research reagent) for $30 \mathrm{~min}$. The final MMT protecting group was removed following the same procedure as for amino-linker couplings. Couplings of additional spermine residues on the resin were equally performed. Yields of spermine coupling steps were calculated on MMT absorbances ratio at $478 \mathrm{~nm}$ and were comprised between $70 \%$ and $88 \%$.

\subsection{General procedure for automated oligonucleotide syntheses on solid-supported spermine oligomers}

Oligonucleotide syntheses were performed as follows: solid-supported spermine oligomers were detritylated before being loaded onto the synthesizer. Junction between spermine oligomer and oligonucleotide was achieved by creating phosphoramidate functionality. To this end, the first nucleotide was coupled with increased reaction time (cycle $\mathrm{X}$ ). To carry out a decamer synthesis, standard instrumental protocol for a $1 \mu \mathrm{mol}$ DNA synthesis was therefore improved by: (1) increasing wash volume after TCA deblocking (total volume $\approx 4 \mathrm{~mL}$ ) for complete DMT recovery, (2) extending capping cycle time (3 min), (3) modifying cycle $\mathrm{X}$ to draw phosphoramidite from position $C$ instead of position 5 . All oligonucleotides were synthesized with final DMT-ON condition by programming the following sequence: 3'-XACCGTAGCG-DMT-5'. Average coupling yields were evaluated by measuring the $503 \mathrm{~nm}$ absorbance of recovered DMT fractions diluted to $100 \mathrm{~mL}$ by $3 \%$ TCA/DCM solution. These yields were comprised between $96.1 \%$ and $99.3 \%$.

\subsection{Cleavage from the support and purification}

The resin was then transferred to a screwcap tube and oligonucleotide-oligospermine was cleaved from the support by action of $0.5 \mathrm{~mL}$ of concentrated ammonia ( $28 \%$ in water) for $24 \mathrm{~h}$ at $\mathrm{rt}$. The solution was next lyophilized and Npeoc protecting groups were removed from the guanidino-spermine tail by suspending oligonucleotide conjugates in a solution of DBU $1 \mathrm{M}$ in acetonitrile $(0.2 \mathrm{~mL})$ at $55^{\circ} \mathrm{C}$ overnight and $48 \mathrm{~h}$ at room temperature. Acetonitrile from the resulting products was removed by lyophilisation and the samples were dissolved in $\mathrm{H}_{2} \mathrm{O} \mathrm{mQ}(0.4 \mathrm{~mL})$. DMT-oligonucleotide-oligospermines were then purified on a PolyPak II reverse phase cartridge. Standard procedure ${ }^{4}$ was followed for the purification of those conjugates, as previously described, except for the elution step, which was accomplished by successive elutions of $20 \%$ acetonitrile in water $(1 \mathrm{~mL})$ and ammonia $(1 / 20$ or $1 / 10$; $2 \times 1 \mathrm{~mL}$ ). Oligonucleotide-containing fractions were pooled. Additional desalting step was proven necessary because of residual DBU and was performed on a NAP-5 column, according to the manufacturer's protocol.

\subsection{Melting temperature $\left(T_{m}\right)$ studies}

Melting temperature studies were carried out in $1 \mathrm{~cm}$ path length quartz cells on a CARY 100Bio UV-vis spectrophotometer (Varian, France) by measuring the absorption at $260 \mathrm{~nm}$. The samples were placed in a CARY Thermostatable Multicell Holder accessory (Varian) and the temperature was regulated by a CARY Temperature controller by Peltier effect (Varian). Samples for analysis consisted of a $1.0 \mu \mathrm{M}$ concentration of each oligonucleotide in $1 \mathrm{~mL}$ buffer composed of $10 \mathrm{mM}$ HEPES $\mathrm{pH} 7.4,0.15 \mathrm{M}$ sodium chloride. All samples were annealed by heating at $95^{\circ} \mathrm{C}$ for 20 min before slowly cooling down to $20^{\circ} \mathrm{C}$ The experiments were carried out by increasing the temperature at a rate of $0.7^{\circ} \mathrm{C}$ per minute from 20 to $90^{\circ} \mathrm{C}$ and the temperature was recorded every $0.5^{\circ} \mathrm{C}$. Tm values were taken as the maximum of the first derivative absorption curve versus temperature.

\section{Supplementary data}

Supplementary data associated with this article can be found, in the online version, at doi:10.1016/j.bmc.2011.01.061.

\section{References and notes}

1. Voirin, E.; Behr, J.-P.; Kotera, M. Nat. Protocols 2007, 2, 1360.

2. Pons, B.; Kotera, M.; Zuber, G.; Behr, J.-P. ChemBioChem 2006, 7, 1173.

3. Nothisen, M.; Kotera, M.; Voirin, E.; Remy, J.-S.; Behr, J.-P. J. Am. Chem. Soc. 2009, 131, 17730.

4. Noir, R.; Kotera, M.; Pons, B.; Remy, J.-S.; Behr, J.-P. J. Am. Chem. Soc. 2008, 130, 13500.

5. Moreau, V.; Voirin, E.; Paris, C.; Kotera, M.; Nothisen, M.; Remy, J.-S.; Behr, J.-P.; Erbacher, P.; Lenne-Samuel, N. Nucleic Acids Res. 2009, 37. e130/1-e130/14.

6. Dempcy, R. O.; Browne, K. A.; Bruice, T. C. Proc. Natl. Acad. Sci. U.S.A. 1995, 92, 6097.

[7]. Park, M.; Bruice, T. C. Bioorg. Med. Chem. Lett. 2010, 20, 3982. and references cited therein.

8. Schneider, S. E.; Bishop, P. A.; Salazar, M. A.; Bishop, O. A.; Anslyn, E. V. Tetrahedron 1998, 54, 15063.

9. Manimala, J. C.; Anslyn, E. V. Eur. J. Org. Chem. 2002, 3909. and references cited therein.

10. Zhang, Z.; Pickens, J. C.; Hol, W. G. J.; Fan, E. Org. Lett. 2004, 6, 1377.

11. Deglane, G.; Abes, S.; Michel, T.; Prévot, P.; Vives, E.; Debart, F.; Barvik, I.; Lebleu, B.; Vasseur, J.-J. ChemBioChem 2006, 7, 684.

12. Pak, J. K.; Hesse, M. Helv. Chim. Acta 1998, 81, 2300.

13. Lang, H.; Gottlieb, M.; Schwarz, M.; Farkas, S.; Schulz, B. S.; Himmelsbach, F.; Charubala, R.; Pfleiderer, W. Helv. Chim. Acta 1999, 82, 2172.

14. Yield of single step are usually from $30 \%$ to $37 \%$.

15. In a preliminary study, it was shown that the solid phase guanidine link forming reaction on $5^{\prime}$-aminolinker conjugated oligonucleotides can be done for the first coupling while further coupling is not efficient presumably because of partial deprotection of phosphate group during base catalyzed coupling reaction.

16. Coupling yields ranged between $70 \%$ and $88 \%$.

17. Phosphoramidate links were formed. Phosphoramidate functions are known to be resistant to basic conditions so that the oligonucleotide conjugate could be cleaved and deprotected under standard conditions. See: Letsinger, R. L.; Mungall, W. S. J. Org. Chem. 1970, 35, 3800.

18. We preferred two-step procedure. We observed that on-column Npeoc deprotection with DBU/ACN induces a significant amount of ODN cleavage from CPG. ${ }^{19-21}$

19. Stengele, K.-P.; Pfleiderer, W. Tetrahedron Lett. 1990, 31, 2549.

20. Browne, T.; Pritchard, C. E.; Turner, G.; Salisbury, S. A. J. Chem. Soc., Chem. Commmun. 1989, 891.

21. Ferrer, E.; Neubauer, G.; Mann, M.; Eritja, R. J. Chem. Soc., Perkin Trans. 1 1997, 2051.

22. Damha, M. J.; Ogilvie, K. K. In Protocols for Oligonucleotides and Analogs. Synthesis and Properties; Agrawal, S., Ed.; Humana Press Inc.: Totowa, New Jersey, 1993; p 81. Chapter 5. 